\title{
A Review of Potential Candidate Genes Polymorphism Responsible For Schizophrenia Risk
}

\author{
Indu Priya ${ }^{1}$, Sakshi Sharma ${ }^{2}$, Isar Sharma ${ }^{2}$, Ritu Mahajan ${ }^{3}$ and Nisha Kapoor ${ }^{3 *}$ \\ ${ }^{1,2,3}$ School of biotechnology, University of Jammu, India \\ *Corresponding author: immunogenomicsbtju@gmail.com,nisha2208@gmail.com, 9622049666
}

Available online at: www.isroset.org

Received: 06/Dec/2018, Accepted: 21/Dec/2018, Online: 31/Dec/2018

\begin{abstract}
Schizophrenia (SCZ) is a strong heritable disorder that involves multiple gene combination, each conferring a little increase in the burden to the disease. Due to the complexity of disease, it is difficult to find susceptible genes and promising biomarker. The true etiology of SCZ is still not fully understood, however, recent studies on SCZ molecular genetics, with a focus on candidate genes approach affirms and predicate association with SCZ. Some investigators have reported the involvement of environment factors in the formation and progression of the Schizophrenia. Literature has been surveyed that reports association between genetic variation and SCZ also between genetic polymorphisms and clinical outcomes. The present study focuses on human populations to review SNPs of various genes which show best association with the disease. We have identified 60 published case control studies that have studied association of various SNPs in different population.
\end{abstract}

Keywords: Association studies, Schizophrenia, SNPs, Genes, Inheritance.

\section{INTRODUCTION}

Schizophrenia is a complicated neuropsychotic disorder characterized by various symptoms like lack of speech, interference in cognition and emotion, hallucinations and delusions [1]. Approximately $1 \%$ of the general population worldwide is affected by schizophrenia and it is eighth leading cause of disability adjusted life years [2]. It has been confirmed by various studies that this disorder possess high range of heritability and there could be many potential candidate gene that are dysregulated during development and can lead to the progression of schizophrenia symptoms [3, 4]. In the current years, progress in neuroimaging, molecular biology and genetic techniques has provided new insights into the biology of schizophrenia [5]. There are innumerable reports of genes and various new loci that have been recognized to be associated with the disorder however, genetic research aiming efficient characterization of SCZ is needed that can help in very early stage detection of endophenotypes, identifying parents that have schizophrenic descendants and identifying the schizophrenia patients that are unresponsive to antipsychotic medication. In spite of numerous studies much of the genetic variation that may be the primary cause of the disease pathology is still not very well known [6]. Investigation of changes in DNA and the molecular mechanisms revealed that environmental factors can act on the genome [7] and Gene-environment interactions are responsible for the etiology of schizophrenia [8]. Research on polymorphism in SCZ is relevant as the disease is highly heritable. Moreover, SCZ resistance to drug treatment $[9,10]$ also make polymorphism study important. However, association studies of polymorphism in SCZ provide the first step for evaluating diagnostic criteria, they are not sufficient to inform therapies.

In this ambience, association of genetic polymorphisms may provide evidence for the cause of schizophrenia and will also identify genes that are strong candidates for further study. Previous studies discussed the association of certain genes (catecholO-methyltransferase (COMT), brain-derived neurotrophic factor (BDNF), FK506-binding protein 5 (FKBP5), neuregulin, dysbindin, DISC1, RGS4, GRM3 and G72) in relation to SCZ [11, 12]. The current study focuses on the association of SCZ with a gene pool of 45 candidate genes. 


\section{METHOD}

Literary works Search. Google scholar, pubmed-NCBI, MEDLINE, Education resource information centre(ERIC) and The Cumulative Index to Nursing and Allied Health Literature (CINAHL) were used for published studies for 2010-2017, using the search terms "genetic polymorphism and Schizophrenia". We also searched for studies on each specific candidate gene: for example, for NOTCH 4 the terms "NOTCH4" and "Schizophrenia" were used. Also, the bibliographies of reports identified by the electronic searches were hand searched. Eligible studies were those that compared genotypic or allele frequencies of candidate genes in a series of Schizophrenia with a series of healthy controls using genomic DNA. Studies from clinical trials, metaanalyses and reviews were included. Publication from non-english languages, GWAS and animal models/cell lines were also excluded.

\section{RESULTS AND DISCUSSION}

We selected 60 original articles that identified genetic polymorphism as associated or not associated with schizophrenia and were published between 2010-2017.Worldwide ethnic groups were included in the article though the basic study design was same in all the reports. We selected only those which included an identification code for the polymorphisms. Together, these articles identified 45 genes (Table 1).

Table1: Genetic polymorphism and functional effect studied in relation to schizophrenia

\begin{tabular}{|c|c|c|c|}
\hline Gene & Polymorphism & Amino acid change & Functional effect \\
\hline BDNF & $\begin{array}{l}\text { In the } 5 \text { ' pro-region of } \\
\text { BDNF }\end{array}$ & Val to met at codon 66 & Reduced activity \\
\hline DISC1 & rs821633 & None & Not studied \\
\hline NOTCH 4 & $\begin{array}{l}\text { rs204993(3' UTR re- } \\
\text { gion), (CTG)n A-G } \\
\text { substitution }\end{array}$ & None & Not studied \\
\hline MTNR 1A & $\begin{array}{l}\text { rs2119882 (promoter } \\
\text { region) }\end{array}$ & None & Not Studied \\
\hline $\begin{array}{l}\text { IL1B, IL1RN, IL6R, } \\
\text { IL10, } \\
\text { IL10RA, TGF1B }\end{array}$ & $\begin{array}{l}\text { rs4848396(IL1B), } \\
\text { rs453745 \& rs2228145 } \\
\text { (IL6R), } \\
\text { rs4251961(IL1RN), } \\
\text { rs1800872 } \\
\text { rs1800871(IL10), } \\
\text { rs1800470 \& rs1800469 } \\
\text { in TGFB1 }\end{array}$ & None & Not studied \\
\hline C1QB & rs $291982 * \mathrm{G}$ & None & $\begin{array}{l}\text { Overrepresented in } \\
\text { schizophrenic patients }\end{array}$ \\
\hline $\begin{array}{l}\text { SLC6A2, SLC6A3 and } \\
\text { DRD2 }\end{array}$ & 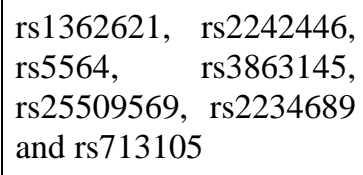 & None & Not studied \\
\hline $\begin{array}{l}\text { MCPH1, } \\
\text { CZC31H } \\
\text { \& BICD2 }\end{array}$ & $\begin{array}{l}\text { rs } 2853884, \quad \text { rs3436975 } \\
\& \quad \text { rs4332968(BICD2), } \\
\text { rs11106470(D2G3) }\end{array}$ & None & Not Studied \\
\hline COMT & met/met homozygote & Val to met & Not Studied \\
\hline
\end{tabular}




\begin{tabular}{|c|c|c|c|}
\hline $\begin{array}{l}\text { CYP1A2 } \\
\text { CYPD6 }\end{array}$ & rs762551 & None & Not Studied \\
\hline GRIN1 & G1001C & None & Not studied \\
\hline DRD3 & Ser9Gly & None & Not Studied \\
\hline IL-6 \& IL-10 & $\begin{array}{l}\text { GC at-174(IL-6) } \\
\text { GG at }-108(\mathrm{IL}-10)\end{array}$ & None & Not Studied \\
\hline IL-2, IL-6 \& TNF $\alpha$ & $\begin{array}{l}\text { rs2069762,rs1800795, } \\
\text { rs1800629 }\end{array}$ & None & Not studied \\
\hline PPAR $\gamma 2$ & Pro12Ala \& C161T & None & Not Studied \\
\hline MAD1L1 & rs12666575 & None & $\begin{array}{l}\text { MAD1L1 rs12666575 } \\
\text { polymorphism was sig- } \\
\text { nificantly associated } \\
\text { with schizophrenia sus- } \\
\text { ceptibility in recessive } \\
\text { mode. Therefore, } \\
\text { rs12666575 may be as- } \\
\text { sociated with gen- } \\
\text { eral psychopatholo- } \\
\text { gy and thought dis- } \\
\text { turbance in Schizo- } \\
\text { phrenics. }\end{array}$ \\
\hline TGF $\beta 1$ & $-1869 \mathrm{TTC}(\mathrm{rs} 1800470)$ & None & Not Studied \\
\hline 5HT1A \& 5HTTLPR & rs6295 & None & $\begin{array}{l}\text { Both the genes has an } \\
\text { influence on the nega- } \\
\text { tive symptoms of SZ }\end{array}$ \\
\hline KMO & rs 1053230 & None & Not Studied \\
\hline SOD & Ala9Val & None & $\begin{array}{l}\text { Reduced activity associ- } \\
\text { ated with Tardive dyski- } \\
\text { nesia in schizophrenics }\end{array}$ \\
\hline DTNBP1 & $\mathrm{G} / \mathrm{C}$ and $\mathrm{C} / \mathrm{T}$ & None & Not studied \\
\hline COMT & Val108/158met & None & $\begin{array}{l}\text { COMT val108/158 met } \\
\text { polymorphism has no } \\
\text { influence in the clinical } \\
\text { symptomatology of } \\
\text { schizophrenia }\end{array}$ \\
\hline DNMT & $\begin{array}{l}\text { rs211472 and } \\
\text { rs2228611 }\end{array}$ & None & Not studied \\
\hline NRG1, TNF $\alpha$ and $\beta$ & $\begin{array}{l}\text { G/G(NRG1) and } \\
\text { A/A(TNF } \alpha)\end{array}$ & None & Not studied \\
\hline $5 \mathrm{HT} 2 \mathrm{~A}$ & rs6311 and rs6313 & None & Not studied \\
\hline DBH & rs1611114 & None & $\begin{array}{l}\text { Lower DBH mRNA } \\
\text { expression levels in }\end{array}$ \\
\hline
\end{tabular}




\begin{tabular}{|l|l|l|l|}
\hline & & & $\begin{array}{l}\text { Schizophrenics than } \\
\text { healthy controls }\end{array}$ \\
\hline DEGS2 & rs3783332 & None & Not studied \\
\hline ZNF804 $\alpha$ & rs1344706 & None & Not studied \\
\hline CMYA5 & A/A(rs6883197) & None & Not studied \\
\hline IL-18 & $\begin{array}{l}-137 \text { G/C } \\
-607 C / A\end{array}$ & None & Not studied \\
\hline ARHGAP1 & $\begin{array}{l}\text { rs7758025 } \\
\text { rs9483050 }\end{array}$ & None & Not studied \\
\hline
\end{tabular}

Although 45 genes have been studied, most of them were reported to contain significant associations with the disorder in one population but often not been confirmed by other studies in different population for the same polymorphism.

\section{GENETICS OF SCHIZOPHRENIA}

Genetics seems to play a major role in development of schizophrenia, as evident from various studies where estimated heritability of the disease is found to be around $70-90 \%[13,14]$. Also, it has been seen that people with family history of schizophrenia are fifty times more likely to develop this disorder than unrelated individuals (www.schizophrenia.com/research/hereditygen.html). Denovo mutations and increased paternal age at conception also contributes to the susceptibility of schizophrenia $[15,16,17]$. Data from combining several studies has suggested that the chromosome 6p MHC region and some other genes (NRGN and TCF4) play a major role in the genetics of schizophrenia [18, 19, 20]. Many individuals with no known history of schizophrenia (familial subtypes) are also affected by this disease indicating that genetics alone is not responsible for causing disease and other factors are involved as well. It is also established that schizophrenics have increased rare CNVs than healthy controls [21] and the rate of de novo mutations in CNVs of schizophrenia affected individuals is high $(\sim 5 \%)$ than controls $(\sim 2 \%)[22,23]$.

\section{GENETIC POLYMORPHISM}

SNPs are being targeted for studying polymorphism than any other marker because SNPs are distributed within or outside the gene region with a frequency of higher than $1 \%$ in the human genome. 54\% of SNP variants are not harmful [24]. The occurrence and risk associated with the disease can be modified by SNPs either alone or in linkage disequilibrium with one gene or in neighbourhood genes. In 2014, a very large genome wide association study identified 108 common SNPs possibly associated with schizophrenia [25]. There were approximately 8000 SNPs that independently contributed to the disorder, which indicated there is more than 50\% genetic susceptibility [26]. Large number of groups working on SNPs have identified thousands of genetic loci associated with schizophrenia. The link between genes and disease is far more complex than ever anticipated. Detection of polymorphism enables the identification of risk factors or protective factors that affect the development of schizophrenia. Thus, in this review we seek to report the articles that investigated the association of genetic polymorphism with schizophrenia.

Association of genetic polymorphism with Schizophrenia studied by authors is given in Table 2.

i) The BDNF gene: Polymorphism has been investigated in brain derived neurotrophic factor (BDNF) gene in four studies. Huang and Lee found BDNF G196 polymorphism was identified with the risk to suicide history in schizophrenia patients of Taiwanese ethinicity. This study revealed that patients with suicide history had lower frequency of the GG genotype (25\%) and GA genotype (37.5\%) and greater frequency of the AA genotype (37.5\%) than patients without suicide history [27]. Wenjun Li et al., found a trend toward significant overall differences in the estimated haplotype frequencies, with more frequent haplotype ATC of rs6265, rs12273539 and rs10835210 polymorphisms of BDNF gene in Schizophrenia patients than in controls and contributed to the negative symptoms of the disease [28]. In third study, Zhang et al. found that BDNF gene rs10835210 polymorphism was associated with positive symptoms in schizophrenia patients of Chinese Han population [29] In fourth study, Xia et al. found no remarkable differences in val66met genotype and allelic sharing between patients and healthy individuals. However, they found val allele (0.023) and val/val genotypes (0.058) association with suicide history of schizophrenics [30]. ii) NOTCH 4 gene: Conflicting results have been reported in three studies of neurogenic locus notch homolog 4 (NOTCH 4) gene. Wei and Hemmings found in the 80 British parent offspring trios analysis that an A to G substitution in the promoter 
region and mutations in CTG repeat site in exon 1 of NOTCH 4 gene as candidate gene for Schizophrenia [31] but findings not confirmed by Imai et al., in Japanese population [32]. In other study by Zhang et al., where they found NOTCH 4 gene polymorphism rs204993 to be associated with a higher risk of schizophrenia Chinese Han population[33].

iii) MTNR1A and MTNR1B gene: Park et al., studied two polymorphisms in melatonin receptor (MTNR1A and MTNR1B) genes in Korean population with 289 subjects and 505 controls and found rs2119882 polymorphism of MTNR1A to be associated with schizophrenia and insomnia symptoms in SCZ patients whereas rs4753426 polymorphism of MTNR1B was not associated with schizophrenia [34].

iv) IL genes: Schizophrenia has some relation with a large range of autoimmune diseases as with a history of any autoimmune disease there is $45 \%$ increase in risk for the disorder [35, 36]. In a study of Interleukins (IL) and interleukins receptor (ILR) genes with 621 subjects and 531 controls in polish population, polymorphisms rs4848306 in IL1B gene, rs4251961 in IL1RN gene, rs2228145 and rs4537545 in IL6R was associated with Schizophrenia while s6676671 in IL10 was associated with early age of onset [37]. Paul-Samojedny et al., examined that IL-6 and IL-10 polymorphisms were risk factors for the development of paranoid Schizophrenia in polish population and revealed that allele C at position -174 of IL-6 and allele G at position-1082 of IL-10 promoter sequences correlated with higher susceptibility to the risk [38](Paul-Samojedny et al., 2010).In another report of Paul-Samojedny et al., they found IL-2, IL-6 and TNF $\alpha$ polymorphism association with paranoid SCZ in polish population [39].

v) C1 component genes: Zakharyan et al., investigated four SNPs of the complex C1Q component genes C1QA (rs292001) and C1QB (rs291982, rs631090, rs913243) in Armenian population and found that rs291982 GG genotype was connected with increased risk for schizophrenia [40].

vi) The COMT gene: Polymorphism in catechol-O methyl transferase (COMT) gene was not directly linked to schizophrenia but associated with aggressive and antisocial behaviour. Rael D Strous found that COMT activity in schizophrenics was reduced and there was Valine to methionine amino acid change [41].

vii) Cytochrome P450 genes: Ivanova et al., studied that polymorphic variants of cytochrome P450 (CYP1A2 and CYP2D6) genes in schizophrenics with Tardive Dyskinesia (TD) and hyperprolactinemia. He found that C-163A of CYP1A2 gene and1846G $>$ A and genotype A/A of CYP2D6 gene were associated with the disease [42].

viii) DRD3 gene: Scharfetter et al., studied dopamine receptor D3 (DRD3) polymorphism in Pakistani patients and noted that there was genetic association with treatment response of clozapine drug. They reported that ser-9/ser-9 genotypes was prevailing in non-responders and Ser-9/Gly-9 genotypes was prevailing in responders while Gly-9/Gly-9 genotypes were found exclusively in responders [43].

ix)PPAR $\gamma 2$ gene: Peroxisome proliferator-activated receptor $\gamma 2(\operatorname{PPAR} \gamma 2)$ gene, a study by Chen et al., found this gene not to be associated with schizophrenia. This gene is reported to be associated with metabolic syndrome in schizophrenics [44].

x) MAD1L1 gene: Su et al., studied mitotic arrest deficient 1 like 1 (MAD1L1) gene polymorphism of rs12666575 with schizophrenia in a Chinese population and showed that the polymorphism was significantly associated with the disease susceptibility in the recessive model. They suggested that MAD1L1 rs12666575 polymorphism may play a protective role against the disorder in Chinese population [45].

xi) TGF $\beta 1$ gene: Frydecka et al., found that polymorphism at $+869 \mathrm{~T}>\mathrm{C}$ of transforming growth factor $\beta 1$ (TGF $\beta 1$ ) gene to be differed significantly between schizophrenics and healthy control [46]. TGF $\beta 1$ gene is positioned at chromosome 5q31-32, and this region has been most frequently identified with schizophrenia in genome wide linkage analysis [47].

xii) KMO gene: Holtze et al., found that Kynurenine 3-monooxygenase (KMO) SNP rs1053230 influnced cerebrospinal fluid (CSF) concentration of Kynurenic acid (KYNA) that found to be increased in schizophrenics [48].

xiii) SOD gene: Hori et al. studied manganese superoxide dismutase (SOD) gene polymorphism in Japanese population with 192 schizophrenics of which 39 were having TD and 153 were not having TD. They found no association with SOD gene polymorphism in schizophrenia without TD but showed significant association of Ala-9val polymorphism of SOD gene in schizophrenia with TD [49].

xiv) DNMT gene: DNA methyltransferases are known for maintaining and constructing new methylation patterns. Saradalekshmi et al., investigated DNA methyltransferases (DNMT) gene polymorphism in south Indian population with Malyalam ethnicity and found polymorphism DNMT3B rs2424932increased the risk of developing schizophrenia in males but not in females, DNMT3B rs1569686 and DNMT3L rs2070565 was found to be associated with early onset of schizophrenia [50].

xv) 5-HT2A receptor gene: 5-Hydroxytryptamine 2A (5-HT2A) receptor gene polymorphism has been studied in south Indian population with Tamil ethnicity by Sujitha et al., and their SNPs analysis revealed that frequencies of GG and CC genotypes were frequent in schizophrenics [51].

xvi) NRG-1 and TNF- $\alpha$ and $\beta$ genes: Naz et al., examined the association between Neregulin-1(NRG-1) and tumour necrosis factor (TNF- $\alpha$ ) polymorphism in Pakistani ethnic group and found that NRG-1 gene showed heterozygous A/G allele polymorphism in schizophrenics while homozygous A/A polymorphism in TNF- $\alpha(-308)$ was present in schizophrenics than in controls [52]. In another study, Kadasah et al., found associations of TNF- $\alpha(-308 \mathrm{G} / \mathrm{A})$ and TNF- $\beta(+252 \mathrm{~A} / \mathrm{G})$ polymorphism with schizophrenia susceptibility in Saudi patients [53]. 
xvii) Dopamine $\beta$-Hydroxylase gene: Long et al., investigated that dopamine $\beta$-hydroxylase gene polymorphism rs1611114 was associated with schizophrenia in the Chinese Zhuang population but not in Chinese Han population [54] because of the heterogeneity of the genome.

xviii) ZNF804a: Girgenti et al reported that zinc finger 804a (ZNF804a) gene was strong candidate susceptibility gene but the molecular function of the gene is unknown. The protein sequence of ZNF804a anticipated to contain C2H2 type zinc finger domain and suggests it plays a role in DNA binding. The group studied transcriptional control of ZNF804a over the expression of several schizophrenia associated genes and directly interacts with chromatin proximal to the promoter regions of PRSS16 and COMT, the two genes they find upregulated by ZNF804a. They also identified several putative SCZ associated genes that are trancriptionally regulated by ZNF804a over expression [55].

xix) SLC6A2, SLC6A3 and DRD2 genes: Bi et al., studied the effect of serotoninergic and dopaminergic pathway genes SLC6A2, SLC6A3 and DRD2 polymorphisms on schizophrenics and found no association of these genes polymorphism with the disease in Han Chinese population [55].

xx) ARHGAP1 gene: Guo et al., studied Rho-GTPase activating protein 1 (ARHGAP1) gene polymorphism in Han Chinese population. The group reported significant association of two SNPs rs7758025 and rs9483050 of ARHGAP1 gene with the disease in Han Chinese population [56].

Xxi) DISC1 gene: Guoqin et al., studied disrupted in schizophrenia 1 gene in Chinese Han population and found remarkable association of rs821633 with SCZ [57]. In other study by Bae et al., reported lack of association of DISC1 polymorphisms with SCZ in Korean population [58].

Xxii) GRIN1 gene: Galehdari examined N-methyl D-aspartate receptor subunit (GRIN1) gene polymorphism in Iranian population. He reported significant association of G1001C polymorphism with SCZ [59].

Being a multifactorial biological disorder, involving multiple genes and environment factors, heretibility cannot be explained by genetics alone, although the genetic contribution is quite high, estimated to be around 60 to $80 \%$ [60, 14].

Table2: Description of association studies of genetic polymorphism

\begin{tabular}{|c|c|c|c|}
\hline Gene & Polymorphism & $\begin{array}{l}\text { Amino acid } \\
\text { change }\end{array}$ & Functional effect \\
\hline BDNF & In the $5^{\prime}$ pro-region of $\mathrm{BDNF}$ & $\begin{array}{l}\text { Val to met } \\
\text { at codon } 66\end{array}$ & Reduced activity \\
\hline DISC1 & rs821633 & None & Not studied \\
\hline NOTCH 4 & $\begin{array}{l}\text { rs204993(3' UTR region), } \\
\text { (CTG)n A-G substitution }\end{array}$ & None & Not studied \\
\hline MTNR 1A & rs2119882 (promoter region) & None & Not Studied \\
\hline $\begin{array}{l}\text { IL1B, IL1RN, IL6R, IL10, } \\
\text { IL10RA, TGF1B }\end{array}$ & $\begin{array}{lr}\text { rs4848396(IL1B), rs453745 \& } \\
\text { rs2228145 (IL6R), } \\
\text { rs4251961(IL1RN), } \\
\text { rs1800872 } \\
\text { rs1800871(IL10), rs1800470 } \\
\& \text { rs1800469 in TGFB1 }\end{array}$ & None & Not studied \\
\hline C1QB & $\mathrm{rs} 291982 * \mathrm{G}$ & None & $\begin{array}{l}\text { Overrepresented in schizophrenic } \\
\text { patients }\end{array}$ \\
\hline SLC6A2, SLC6A3 and DRD2 & $\begin{array}{l}\text { rs } 1362621, \text { rs } 2242446, \\
\text { rs } 5564, \text { rs } 3863145, \\
\text { rs } 25509569, \text { rs } 2234689 \text { and } \\
\text { rs } 713105\end{array}$ & None & Not studied \\
\hline $\begin{array}{l}\text { MCPH1, D2G3, CZC31H } \\
\& \text { BICD2 }\end{array}$ & $\begin{array}{l}\text { rs2853884, rs3436975 \& } \\
\text { rs4332968(BICD2), } \\
\text { rs11106470(D2G3) }\end{array}$ & None & Not Studied \\
\hline
\end{tabular}




\begin{tabular}{|c|c|c|c|}
\hline COMT & met/met homozygote & Val to met & Not Studied \\
\hline $\begin{array}{l}\text { CYP1A2 } \\
\text { CYPD6 }\end{array}$ & rs762551 & None & Not Studied \\
\hline GRIN1 & G1001C & None & Not studied \\
\hline DRD3 & Ser9Gly & None & Not Studied \\
\hline IL-6 \& IL-10 & $\begin{array}{l}\text { GC at-174(IL-6) } \\
\text { GG at }-108(\text { IL-10) }\end{array}$ & None & Not Studied \\
\hline IL-2, IL-6 \& TNF $\alpha$ & $\begin{array}{l}\text { rs2069762,rs1800795, } \\
\text { rs1800629 }\end{array}$ & None & Not studied \\
\hline PPAR $\gamma 2$ & Pro12Ala \& C161T & None & Not Studied \\
\hline MAD1L1 & rs12666575 & None & $\begin{array}{l}\text { MAD1L1 rs12666575 polymor- } \\
\text { phism was significantly associated } \\
\text { with schizophrenia susceptibility in } \\
\text { recessive mode. Therefore, } \\
\text { rs12666575 may be associated with } \\
\text { general psychopathology and } \\
\text { thought disturbance in Schizo- } \\
\text { phrenics. }\end{array}$ \\
\hline TGF $\beta 1$ & $-1869 \mathrm{TTC}(\mathrm{rs} 1800470)$ & None & Not Studied \\
\hline 5HT1A \& 5HTTLPR & rs6295 & None & $\begin{array}{l}\text { Both the genes has an influence on } \\
\text { the negative symptoms of SZ }\end{array}$ \\
\hline KMO & rs 1053230 & None & Not Studied \\
\hline SOD & Ala9Val & None & $\begin{array}{l}\text { Reduced activity associated with } \\
\text { Tardive dyskinesia in schizophren- } \\
\text { ics }\end{array}$ \\
\hline DTNBP1 & $\mathrm{G} / \mathrm{C}$ and $\mathrm{C} / \mathrm{T}$ & None & Not studied \\
\hline COMT & Val108/158met & None & $\begin{array}{l}\text { COMT val } 108 / 158 \text { met polymor- } \\
\text { phism has no influence in the clini- } \\
\text { cal symptomatology of schizo- } \\
\text { phrenia }\end{array}$ \\
\hline DNMT & rs211472 and rs2228611 & None & Not studied \\
\hline NRG1, TNF $\alpha$ and $\beta$ & $\mathrm{G} / \mathrm{G}(\mathrm{NRG} 1)$ and $\mathrm{A} / \mathrm{A}(\mathrm{TNF} \alpha)$ & None & Not studied \\
\hline $5 \mathrm{HT} 2 \mathrm{~A}$ & rs6311 and rs6313 & None & Not studied \\
\hline DBH & rs1611114 & None & $\begin{array}{l}\text { Lower DBH mRNA expression } \\
\text { levels in Schizophrenics than } \\
\text { healthy controls }\end{array}$ \\
\hline DEGS2 & rs3783332 & None & Not studied \\
\hline ZNF804 $\alpha$ & rs 1344706 & None & Not studied \\
\hline CMYA5 & A/A(rs6883197) & None & Not studied \\
\hline IL-18 & $-137 \mathrm{G} / \mathrm{C}$ & None & Not studied \\
\hline
\end{tabular}




\begin{tabular}{|l|l|l|l|}
\hline & $-607 \mathrm{C} / \mathrm{A}$ & & \\
\hline ARHGAP1 & rs7758025 and rs9483050 & None & Not studied \\
\hline
\end{tabular}

[1]. World Health Organization, "The ICD-10 classification of mental and behavioural disorders: Clinical descriptions and diagnostics guidelines", Geneva: World Health Organisation, 1992.

[2]. American Psychiatric Association, Diagnostic and statistical manual of mental disorders (4 ed., text rev.), 2000.

[3]. S.H. Fatemi, T.D. Folsom, "The neurodevelopmental hypothesis of schizophrenia, revisited", Schizophrenia Bulletin, Vol. 35, Issue, 3, pp. 528$548,2009$.

[4]. P.A. Holmans, B. Riley, A.E. Pulver, M.J. Owen, D.B. Wildenauer, P.V. Gejman, ... D.F. Levinson, "Genome wide linkage scan of schizophrenia in a large multicenter pedigree sample using single nucleotide polymorphisms", Molecular Psychiatry, Vol. 14, pp. 786-795, 2009.

[5]. L. Michelon, H. Vallada, "Genetica do transtorno bipolar", Revista Brasileira de Psiquiatria, Vol. 26, pp. 12-16, 2004.

[6]. M. Emily, T. Mailund, J. Hein, L. Schauser, M.H. Schierup, "Using biological networks to search for interacting loci in genome-wide association studies", European Journal of Human Genetics, Vol. 17, pp. 1231-1240, 2006.

[7]. B.P.F. Rutten, J. Mill, "Epigenetic mediation of environmental influences in major psychotic disorders" Schizophrenia Bulletin, Vol. 35, pp. 1045-1056, 2009.

[8]. Y. Ayhana, R. McFarland, M.V. Plentikov, "Animal models of gene -environment interaction in schizophrenia: A dimensional perspective", Progress in Neurobiology, Vol. 136, pp. 1-27, 2015.

[9]. H.Y. Meltzer, "Treatment-Resistant Schizophrenia - The Role of Clozapine" Current Medical Research and Opinion, Vol. 14, pp. 1-20, 1997.

[10]. H. Elkis, P.F. Buckeley, “Treatment Resistant Schizophrenia”, Psychiatric Clinics of North America, Vol. 39, pp. $239-265,2016$.

[11]. P.J. Harrison, D.R Weinberger, "Schizophrenia genes, gene expression, and neuropathology: on the matter of their convergence", Molecular Psychiatry, Vol. 10, pp. 40-68, 2005.

[12]. B. Misiak, F. Stramecki, L. Gawęda, K. Prochwicz, M.M. Sąsiadek, A.A. Moustafa, D. Frydecka, "Interactions Between Variation in Candidate Genes and Environmental Factors in the Etiology of Schizophrenia and Bipolar Disorder: a Systematic Review", Molecular Neurobiology, Vol. 55, pp. 5075-5100, 2017.

[13]. P.F. Sullivan, K.S. Kendler, Neale, "Schizophrenia as a complex trait: evidence from a meta-analysis of twin studies", Archives of General Psychiatry, Vol. 60, pp. 1187-1192, 2003.

[14]. S.S. Kety, "Schizophrenic illness in the families of schizophrenic adoptees: findings from the Danish national sample", Schizophrenia Bulletin, Vol. 14, pp. 217-222, 1998.

[15]. J.A. Veltman, H.G. Brunner, "De novo mutations in human genetic disease", Nature Reviews Genetics, Vol. 13, pp. 565-575, 2012.

[16]. A. Kong, M.L. Frigge, G. Masson, S. Besenbacher, P. Sulem, G. Magnusson, K. Stefansson, "Rate of de novo mutations and the importance of father's age to disease risk", Nature, Vol. 488, pp. 471-475, 2012.

[17]. J.J. McGrath, L. Petersen, E. Agerbo, O. Mors, P. Mortensen, C. Pedersen, “A comprehensive assessment of parental age and psychiatric disorders", JAMA Psychiatry Vol. 71, pp. 301-309, 2014.

[18]. S.M. Purcell, N.R. Wray, J.L. Stone, P.M. Visscher, M.C. O’Donovan, P.F. Sullivan, P. Sklar, "Common polygenic variation contributes to risk of schizophrenia and bipolar disorder", Nature, Vol. 460, pp. 748-752, 2009.

[19]. J. Shi, D.F. Levinson, J. Duan, A.R. Sanders, Y. Zheng, I. Pe'er, F. Dudbridge, P.A. Holmans, A.S. Whittemore, B.J. Mowry, A. Olincy, F. Amin, C.R. Cloninger, J.M. Silverman, N.G. Buccola, W.F. Byerley, D.W. Black, R.R. Crowe, J.R. Oksenberg, D.B. Mirel, K.S. Kendler, R. Freedman, P.V. Gejman, "Common variants on chromosome 6p22.1 are associated with schizophrenia", Nature, Vol. 60, pp. 753-757, 2009.

[20]. H. Stefansson, R.A. Ophoff, S. Steinberg, O.A. Andreassen, S. Cichon, D. Rujescu, ... D.A. Collier, "Common variants conferring risk of schizophrenia", Nature, Vol. 460, pp. 744-747, 2009.

[21]. International Schizophrenia Consortium, "Rare Chromosomal deletions and duplications increase risk of schizophrenia", Nature, Vol. 455, pp. 237-241, 2008.

[22]. D. Malhotra, S. McCarthy, J.J. Michaelson, V. Vacic, E.B. Katherine, S. Yoon, S. Cichon, A. Corvin, S. Gary, S.G. Elliot, M. Gill, M. Karayiorgou, J.R. Kelsoe, O. Krastoshevsky, V. Krause, E. Leibenluft, D.L. Levy, V. Makarov, A. Bhandari, A.K. Malhotra, F.J. McMohan, M.M. Nathan, J.B. Potash, M. Rietschell, T.G. Schilze, J. Sebat, "High frequencies of de novo CNVs in bipolar disorder and schizophrenia", Neuron, Vol. 72, pp. 951-963, 2011.

[23]. B. Xu, J.L. Roos, J.L., S. Levy, E.J.V. Rensburg, J.A. Gogos, M. Karayiorgou, "Strong association of de novo copy number mutations with sporadic schizophrenia”, Nature Genetics, Vol.40, pp. 880-885, 2008.

[24]. A.A. Mitchell, A. Chakravarti, D.J. Cutler, D.J, "On the probability that a novel variant is a disease-causing mutation", Genome Research, Vol. 15, pp. 960-996, 2005.

[25]. Schizophrenia Working Group of the Psychiatric Genomics Consortium, S. Ripke, B.M. Neale, A. Corvin, J.T.R. Walters, ... M.C. O'Donovan, "Biological Insights From 108 Schizophrenia-Associated Genetic Loci", Nature, Vol. 511, pp. 421-427, 2014.

[26]. S. Ripke, C. O’Dushlaine, K. Chambers, J.L. Moran, A.K. Kahler, S. Akterin, ... P.F. Sullivan, “Genome-wide association analysis identifies 13 new risk loci for schizophrenia", Nature Genetics, Vol. 45, pp. 1150-115, 2013.

[27]. T.L. Huang, T.C. Lee, "Associations between Brain-derived Neurotrophic Factor G196A Gene Polymorphism and Clinical Phenotypes in Schizophrenia Patients", Chang Gung Medical Journal, Vol. 30, pp. 408-413, 2007.

[28]. W. Li, N. Zhou, Q. Yu, X. Li, Y. Yu, S. Sun, C. Kou, D.C. Chen, M.H. Xiu, T.R. Kosten, X.Y. Zhang, “Association of BDNF gene polymorphisms with schizophrenia and clinical symptoms in a chinese population”, American Journal of Medical Genetics, 2013. 
[29]. X.Y. Zhang, D.C. Chen, Y.L. Tan, Y.L. Tan, S.P. Tan, X. Luo, L. Zuo, J.C. Soares, "BDNF polymorphisms are associated with schizophrenia onset and positive symptoms" Schizophrenia Research, Vol. 170, pp. 41-47, 2016.

[30]. H. Xia, G. Zhang, X. Du, Y. Zhang, G. Yin, J. Dai, M.X. He, J.C. Soares, X. Li, X.Y. Zhang, "Suicide Attempt, Clinical Correlates, and BDNF Val66Met Polymorphism in Chronic Patients With Schizophrenia", Neuropsychology, 2017.

[31]. P.J. Harrison, D.R. Weinberger, "Schizophrenia genes, gene expression, and neuropathology: on the matter of their convergence", Molecular Psychiatry, Vol. 10, pp. 40-68, 2005.

[32]. K. Imai, S. Harada, Y. Kawanishi, H. Tachikawa, T. Okubo, T. Suzuki, "The (CTG)n polymorphism in the NOTCH4 gene is not associated with schizophrenia in Japanese individuals", BMC Psychiatry, Vol. 1, pp. 1, 2001.

[33]. B. Zhang, Q.R. Fan, W.H. Li, N. Lu, D.K. Fu, Y.J. Kang, N. Wang, T. Li, X.P. Wen, X.D. Li, "Association of the NOTCH4 Gene Polymorphism rs204993 with Schizophrenia in the Chinese Han Population”, BioMedical Research International, Vol. 408096, 2015.

[34]. H.J. Park, J.K. Park, S.K. Kim, A.R. Cho, J.W. Kim, S.V. Yim, J.H. Chung, “Association of Polymorphism in the Promoter of the Melatonin Receptor 1A Gene with Schizophrenia and with Insomnia Symptoms in Schizophrenia Patients", Journal of Molecular Neuroscience, Vol. 45, pp. 304, 2011.

[35]. M.E. Benros, P.B. Mortensen, W.W. Eaton, "Autoimmune diseases and infections as risk factors for schizophrenia", Annals of the New York Academics Science, Vol. 1262, pp.56-66, 2012.

[36]. W.W. Eaton, M. Byrne, H. Ewald, O. Mors, C.Y. Chen, E. Agerbo, P.B. Mortensen, "Association of schizophrenia and autoimmune diseases: linkage of Danish national registers", American Journal of Psychiatry, Vol. 163, Issue, 3, pp. 521-528, 2006.

[37]. P. Kapelski, M. Skibinska, M. Maciukiewicz, M. Wilkosc, D. Frydecka, A. Groszewska, B. Narozna, M. Dmitrzak-Weglarza, P. Czerskia, A. Pawlaka, A. Rajewska-Rager, A. Leszczynka-Rodziewicz, A. Slopienh, D. Zaremba, J. Twarowska-Hauser, "Association study of functional polymorphisms in interleukins and interleukin receptors genes: IL1A, IL1B, IL1RN, IL6, IL6R, IL10, IL10RA and TGFB1 in schizophrenia in Polish population", Schizophrenia Research, Vol. 16, pp. 1-9, 2015.

[38]. M. Paul-Samojedny, M. Kowalczyk, R. Suchanek, A. Owczarek, A. Fila-Danilow, A. Szczygiel, J. Kowalski, "Functional Polymorphism in the Interleukin-6 and Interleukin-10 Genes in Patients with Paranoid Schizophrenia - A Case-Control Study", Journal of Molecular Neuroscience, Vol. 42, pp. 112-119, 2010.

[39]. M. Paul-Samojedny, A. Owczarek, M. Kowalczyk, R. Suchanek, M. Palacz, K. Kucia, A. Fila-Daniłow, P. Borkowska, J. Kowalski, “Association of interleukin 2 (IL-2), interleukin 6 (IL-6), and TNF-alpha (TNF $\alpha$ ) gene polymorphisms with paranoid schizophrenia in a Polish population", Journal Neuropsychiatry and Clinical Neuroscience, Vol. 25, pp.72-82, 2013.

[40]. R. Zakharyan, A. Khoyetsyan, A. Arakelyan, A. Boyajyan, A. Gevorgyan, A. Stahelova, F. Mrazek, M. Petrek, "Association of C1QB gene polymorphism with schizophrenia in Armenian population”, BMC Medical Genetics, Vol. 12, pp. 126, 2011.

[41]. R.D. Strous, N.G. Bark, S.S. Parsia, J. Volavka, H.M. Lachmanc, "Analysis of a functional catechol-O-methyltransferase gene polymorphism in schizophrenia: evidence for association with aggressive and antisocial behaviour", Psychiatry Research, Vol. 69, pp. 71-77, 1997.

[42]. S.A. Ivanova, M.L. Filipenko, N.M. Vyalova, E.N. Voronina, V.I. Pozhidaev, D.Z. Osmanova, M.V. Ivanov, O.Y. Fedorenko, A.V. Semke, N.A. Bokhan, N.A. (2015). CYP1A2 and CYP2D6 Gene Polymorphisms in Schizophrenic Patients with Neuroleptic Drug-Induced Side Effects. Bulletin of Experimental Biology and Medicine, Vol. 160, pp. 5, 2015.

[43]. J. Scharfetter, H.R. Chaudhry, K. Hornik, K. Fuchs, W. Sieghartd, S. Kaspera, H.N. Aschauera, "Dopamine D3 receptor gene polymorphism and response to clozapine in schizophrenic Pakistani patients", European Neuropsychopharmacology, Vol. 10, pp. 17-20, 1990.

[44]. C.H. Chen, M.L. Lua, P.H. Kuoc, P.Y. Chene, C.C. Chiu, C.F. Kaoc, M.C. Huang, "Gender differences in the effects of peroxisome proliferator activated receptor $\gamma 2$ gene polymorphisms on metabolic adversity in patients with schizophrenia or schizoaffective disorder", Progress in Neuropsychopharmacology and Biological Psychiatry, Vol. 35, Issue, 1, pp. 239-245, 2011.

[45]. L. Su, T. Shen, G. Huang, J. Long, J. Fan, W. Ling, J. Jiang, "Genetic association of GWAS-supported MAD1L1 gene polymorphism rs 12666575 with schizophrenia susceptibility in a Chinese population", Neuroscience Letter, Vol. 610, pp. 98-103, 2016.

[46]. D. Frydecka, B. Misiak, J.A. Beszlej, L. Karabon, E. Pawlak-Adamska, A. Tomkiewicz, A. Partyka, A. Jonkisz, A. Kiejna, "Genetic variants in transforming growth factor- $\beta$ gene (TGFB1) affect susceptibility to schizophrenia", Molecular Biology Reports, Vol. 40, Issue, 10, pp. 56075614, 2013.

[47]. C.M. Lewis, D.F. Levinson, L.H. Wise, L.E. DeLisi, R.E. Straub, I. Hovatta, ... T. Helgason, "Genome-scan meta analysis of schizophrenia and bipolar disorder, partII: Schizophrenia", American Journal Human Genetics, Vol. 73, pp. $34-48,2009$.

[48]. M. Holtze, P. Saetre, G. Engberg, L. Schwieler, T. Werge, O.A. Andreassen, H. Hall, L. Terenius, I. Agartz, E.G. Jonsson, M. Schalling, S. Erhardt, "Kynurenine 3-monooxygenase polymorphisms:relevance for kynurenic acid synthesis in patients with schizophrenia and healthy controls", Journal of Psychiatry Neuroscience, Vol. 37, pp. 1, 2011.

[49]. H. Hori, O. Ohmori, T. Shinkai, H. Kojima, C. Okano, T. Suzuki, J. Nakamura, "Manganese Superoxide Dismutase Gene Polymorphism and Schizophrenia: Relation to Tardive Dyskinesia", Neuropsychopharmacology, Vol. 23, pp. 2, 2000.

[50]. K.R. Saradalekshmi, N.V. Neetha, S. Sathyan, I.V. Nair, C.M. Nair, M. Banerjee, "DNA Methyl Transferase (DNMT) Gene Polymorphisms Could Be a Primary Event in Epigenetic Susceptibility to Schizophrenia.”, Plos One, 2014.

[51]. S.P Sujitha, A. Nair, M. Banerjee, S. Lakshmanan, S. Harshavaradhan, S. Gunasekaran, A. Gopinathan, "5-Hydroxytryptamine (serotonin) 2A receptor gene polymorphism is associated with schizophrenia", Indian Journal Medical Research, Vol. 140, pp. 736-743, 2014.

[52]. M. Naz, M. Riaz, M. Saleem, "Potential role of Neurkgulin 1 and TNFalpha (-308) polymorphism in schizophrenia patients visiting hospitals in Lahore, Pakistan", Molecular Biology Reports, Vol. 38, pp. 4709-4714, 2011.

[53]. S. Kadasah, M. Arfin, S. Rizvi, M. Al-Asmari, A. Al-Asmari, "Tumor necrosis factor- $\alpha$ and $-\beta$ genetic polymorphisms as a risk factor in Saudi patients with schizophrenia", Neuropsychiatric and Disease Treatment, Vol. 13, pp. 1081-1088, 2017.

[54]. J. Long, G. Huang, B. Liang, W. Ling, X. Guo, J. Jiang, L. Su, "The dopamine beta-hydroxylase gene polymorphism rs1611114 is associated with schizophrenia in the Chinese Zhuang but not Chinese Han population”, Molecular Genetics and Genomics, Vol. 291, pp. 1813-1821, 2016.

[55]. M.J. Girgenti, J.J. LoTurco, B.J. Maher, “ZNF804a Regulates Expression of the Schizophrenia-Associated Genes PRSS16, COMT, PDE4B, and DRD2", PLOS ONE, 2012. 
[55]. Y. Bi, X. Huang, W. Niu, S. Chen, X. Wu, Y. Cao, R. Zhang, F. Yang, L. Wang, W. Li, Y. Xu, L. He, T. Yu, G. He, X. Li, X., "No association between SLC6A2, SLC6A3, DRD2 polymorphisms and schizophrenia in the Han Chinese population", Psychiatry Research, Vol. 53, pp. 398400, 2017.

[56]. W. Guo, Y.Z. Cai, H. Zhang, Y. Yang, G. Yang, X. Wang, ... L. Lv, “Association of ARHGAP18 polymorphisms with schizophrenia in the Chinese-Han population”, PLOS ONE, 2017.

[57]. H.U. Guoqin, C. Yang, J. Zhao, M. ZHU, X. GUO, C. BAO, ... Z. YI, “Association of schizophrenia with the rs821633 polymorphism in the DISC1 gene among Han Chinese", Shanghai Archives of Psychiatry, Vol. 25, pp. 348-355, 2015.

[58]. J.S. Bae, J.Y. Kim, B. Park, H.S. Cheong, J.S. Kim, J.G. Shin, ... S. Woo, "Lack of association between DISC1 polymorphisms and risk of schizophrenia in a Korean population”, Psychiatry Research, Vol. 208, pp. 189-191, 2013.

[59]. H. Galehdari, "Association Between the G1001C Polymorphism in the GRIN1 Gene Promoter and SchizOphrenia in the Iranian Population", Journal of Molecular Neuroscience, Vol. 38, pp. 178, 2009.

[60]. P.F. Sullivan, K.S. Kendler, Neale, "Schizophrenia as a complex trait: evidence from a meta-analysis of twin studies", Archives of General Psychiatry, Vol. 60, pp. 1187-1192, 2003. 